\title{
Professional or Clerical: A Cross-Validation Study
}

\begin{abstract}
A list of library tasks-of which half were professional and half were nonprofessional-was given to 221 librarians in Michigan, who were asked to indicate which duties absorbed their time. About two-thirds of the total duties reported as performed by these librarians are considered professional. Senior librarians in the public services of academic libraries performed the highest percentage of professional duties, and junior librarians in the technical services of non-academic libraries reported doing the most nonprofessional work.
\end{abstract}

I N THE SEPTEMber 1961 issue of the $\mathrm{Li}$ brary Journal, Eugene E. Hart and William Griffith reported the results of a study conducted in California to determine the "involvement of professional librarians in nonprofessional duties." This author has cross-validated the original study, using the same questionnaire on a selected sample of Michigan librarians.

A study was recently completed to determine the aptitudinal requirements for professional librarians. The results of this study will be used in the vocational counseling of youth and may attract more qualified young people into the library profession. Hart and Griffith's questionnaire was administered to the librarian sample as part of the job analysis phase of this study, and the results were also analyzed to determine the per cent of professional duties performed by various types of librarians. The questionnaire, containing fifty professional and fifty nonprofessional duties randomly distributed, taken primarily from the $A L A$ Descriptive List of Professional and Non-Professional Duties in Libraries, was

Mr. Mathis, a test-research technician with the Michigan Employment Security Commission, resides at 5915 Fourth Street, Detroit. completed by 221 librarians from the following organizations:

Detroit public library

Wayne County library

Pontiac public library

State of Michigan library

Flint public library

Kent County library

Lansing public library

Wayne State University library

Michigan State University library

University of Michigan library

Grand Rapids public library

Only professional librarians with a minimum of six months' experience were administered the questionnaire. To prevent errors of contamination, the following categories of librarians were considered nontypical and were not included in the analysis of data:

1. State of Michigan librarians

2. Community-service librarians

3. Administrative librarians

4. Librarians of undetermined classification level

Fifty-eight individuals were thus eliminated, leaving a total 163 in the sample.

For the purposes of this cross-validation study, only those duties which li- 
brarians indicated were performed more than three hours per week were considered. The table shows the total number of duties performed by each type of librarian, and the number and per cent of professional duties this included. In analyzing the per cent of professional duties performed, the total sample of 163 was broken into smaller categories to distinguish between various types of librarians. Three basic distinctions are considered: college $v s$. noncollege librarians, "junior" vs. "senior" librarians, and public service $v s$. nonpublic service librarians. In the "nonpublic service" category are included catalogers, acquisition librarians, bibliographers, etc. "Junior" librarians are those whose classification level is "assistant librarian" or "librarian I" in their respective organizations. "Senior" librarians are those classified as "Librarian II or above."

As can be seen from the table, approximately two-thirds (weighted mean across all subsamples) of the duties performed by the librarians in this sample are professional. As one might expect, a greater proportion of professional duties are performed by college librarians than noncollege, by nonpublic service than public service, and by senior librarians than junior librarians. The only exceptions to this rule seem to be the three junior nonpublic service college librarians who indicate no nonprofessional duties and the one junior nonpublic service noncollege librarian who indicates that only four of her nine significant duties are professional. It is obvious that neither of these two samples are large enough for serious consideration.

A word of caution is put forth regarding these findings: an underlying assumption of this study is that the professional and nonprofessional items on the questionnaire represent enough available choices in both areas to obtain a true picture of the proportion of professional duties performed by each participating member. There is reason to believe that this condition has not been met. Catalogers, acquisitions, and technical service librarians almost universal-

(Continued on page 5s1)

TABLE 1.

\begin{tabular}{|c|c|c|c|c|}
\hline SAMPLe & $\begin{array}{c}\text { NUMBER IN } \\
\text { EACH SAMPLE }\end{array}$ & $\begin{array}{l}\text { Total* } \\
\text { DutIES }\end{array}$ & $\begin{array}{l}\text { Professional } \\
\text { Dutres }\end{array}$ & $\begin{array}{l}\text { Per Cent } \\
\text { of Prof. } \\
\text { Duties }\end{array}$ \\
\hline Total Sample . . & 163 & 1770 & 1150 & 64.97 \\
\hline Total College Sample & 58 & 397 & 286 & 72.04 \\
\hline Total Noncollege Sample & 105 & 1373 & 864 & 62.93 \\
\hline Total Public Service & 114 & 1559 & 1002 & 64.28 \\
\hline Total Nonpublic Service & 49 & 211 & 148 & 70.14 \\
\hline Total Junior Librarians. & 23 & 253 & 149 & 58.89 \\
\hline Total Senior Librarians & 140 & 1517 & 1001 & 65.98 \\
\hline College-Public Service & 24 & 274 & 200 & 72.9 \\
\hline Noncollege-Public Service & 90 & 1285 & 802 & 62.41 \\
\hline College-Nonpublic Service & 34 & 123 & 86 & 69.91 \\
\hline Noncollege-Nonpublic Service & 15 & 88 & 62 & 70.45 \\
\hline College-Public Service-Juniort ${ }^{\dagger}$ & 5 & 35 & 24 & 68.57 \\
\hline College-Public Service-Senior & 19 & 239 & 176 & 73.64 \\
\hline Noncollege-Public Service-Junior & 14 & 201 & 113 & 56.2 \\
\hline Noncollege-Public Service-Senior & 76 & 1084 & 689 & 63.56 \\
\hline College-Nonpublic Service-Junior ${ }^{\dagger}$ & 3 & 8 & 8 & 100.00 \\
\hline College-Nonpublic Service-Senior & 31 & 115 & 78 & 67.82 \\
\hline Noncollege-Nonpublic Service-Junior ${ }^{\dagger}$ & 1 & 9 & 4 & 44.44 \\
\hline Noncollege-Nonpublic Service-Senior & 14 & 79 & 58 & 73.41 \\
\hline
\end{tabular}

* Total number of items checked as being performed more than three hours per week.

† Sample too small for significance. 
Ellsworth writes about school libraries, the reader may well take issue with his thesis that school libraries were moribund until the 1960's. The American Association of School Librarians' Standards for School Library Programs was based on levels found through research in good school libraries, yet Ellsworth seems to imply that until 1960 good school libraries were virtually nonexistent.

Ellsworth rightly criticizes the quality of the literature of school librarianship, but at the same time ignores important and influential documents. One publication of great import, and one that would have strengthened his case but which he has not mentioned, is Responsibilities of State Departments of Education for School Library Services; a Policy Statement issued by the Council of Chief State Officers in 1961. The council's policy statement, defining the school library as a part of instruction, is one of the most important publications in creating a favorable attitude toward improving school library services. Mr. Ellsworth has overlooked other important contributions to the description of goals for school library programs. Nowhere does he indicate that he is familiar with the writings of Mary Helen Mahar, nor for example, of the original and significant research of Mary V. Gaver.

Ellsworth begins with an enumeration of the factors which have hastened the recent development of school libraries, following with an analysis of "negative forces" which hindered them. Subsequent chapters deal with the proper role and characteristics of school libraries. The book closes with a short look into the future.

Two sections dealing with censorship give disproportionate weight to this problem. The chapter, "The School Library and Community Relations," except for its opening and closing paragraphs, relates exclusively to censorship. More than half of the final chapter is also concerned with censorship and is out of keeping with the tone and method of the rest of the book. If included at all, the final ten pages should have been an appendix.

As a book for school administrators, The School Library will be valuable in presenting a modern and lively concept of library service for secondary schools. Since it is a part of a subscription series, "The Library of Education," in which individual volumes are not sold separately, it may not, however, reach many of the administrators who most need its message. For school administrators seeking a rationale for elementary school library programs, it will not do at all. A book which encompasses school library services at elementary, junior, and senior high school levels remains to be written.-Richard L. Darling, Montgomery County Public Schools, Maryland.

\section{GOVERNMENT PUBLISHING (Continued from page 489)}

and incomplete printing, publishing, and distribution programs are serious. The problems connected with these programs, while not susceptible to easy or cheap solutions, can be overcome provided vigorous, high-level attention is focussed upon them. In any case, their resolution should not be beyond the capacity of a government which can count the number of chickens in Sagadahoc County and send rockets to the moon.

PROFESSIONAL OR CLERICAL . . (Continued from page 526)

ly complained that their job duties were not adequately represented among the professional items on the questionnaire. In this case it is not reasonable to expect the proportion of professional duties indicated to be a true representation.

In conclusion, the findings of the study seem to verify the results obtained by Griffith and Hart that librarians probably perform more nonprofessional duties than they should.

\section{. . UNIVERSITY ARCHIVES (Continued from page 524)}

chives has been stimulated by the writing of a history of the university. ${ }^{35}$ The archival collection in the university archives is as helpful to the historian as the supplementary nonarchival materials attracted to it.

\footnotetext{
${ }^{35}$ Fulmer Mood and Vernon Carstensen, "University Records and Their Relation to General University Administration," CRL, XI (October 1950), 33940.
} 